\title{
Women and their Bodies in the Popular Reading of 1910
}

Kate Macdonald, Ghent University

Abstract: This article discusses the presentation of women's bodies in popular newspapers that reflects an awareness of reproductive health and access to the knowledge and language of sex, 'on or about December 1910'. Originating in Virginia Woolf's biographical writing, diaries and letters, it uses the popular reading of the British public in the Victorian and Edwardian eras, including features and adverts in newspapers, health manuals, and commercially successful novels, to show how Woolf's isolation of a single moment of change for human character was, for most of the population, part of a longstanding social evolution in popular sexual knowledge and moral standards.

Keywords: Women, sex, abortion, Virginia Woolf, H G Wells, Joseph Conrad

\section{Background}

'On or about December 1910 human character changed', wrote Virginia Woolf in her essay 'Character in Fiction' (1924). She personified the moment of this change in 'one's cook', in 'before' and 'after' incarnations. ${ }^{1}$ One woman was 'silent, obscure, inscrutable', whereas the other felt newly free to come and ask her mistress's advice about a hat or to borrow a newspaper. ${ }^{2}$ This combination of hats and newspapers with new conversations across the classes reinforces Woolf's recollection of the insubstantiality of the doors that separated the private lives of the upper classes from their servants. ${ }^{3}$ Starting from Woolf's presentation of this date as a moment of social evolution, this article considers how relations had shifted or were shifting 
between men and women and between the classes at this time, particularly in their sexual lives.

Whether 'on or about December 1910' was the watershed moment and whether there was change in the 1890s or even in the later years of the Edwardian era, are problematic questions. While Woolf said that 'December 1910 ' was a 'vague assertion', she bases the essay on this 'arbitrary' moment. ${ }^{4}$ But I am cautious about focusing on the date alone. Woolf's precise date epitomising a single moment of change is a fragmentation of time that contrasts radically with the idea of a golden and unchanging Edwardian afternoon spanning 1901 to the death of Edward VII, that was routinely presented as a uniform historical phase. This homogenous depiction of Edwardian months and years changed abruptly at the onset of the First World War, when weeks and days were related to deaths and other actions that occurred at precise moments, recorded in the modern technologies of newsprint and photographs. But by asserting that December 1910 was also a rupturing, modern moment, Woolf sought, in hindsight, to break up homogeneity, and highlight moments that were recognisably modern within the swathe of Edwardian time, In 1910 'the state was becoming more anarchic, more uncontrolled, more "modern", ${ }^{5}$ And in asserting the existence of such social change at an arbitrary single moment, Woolf challenged the hegemony of smooth untransitional time with a socially jarring act. While the moment itself may be arbitrary, the fact that Woolf chose a single date, and located it when she did, is important for her presentation of how her life expressed modernity. Her recollection about her cook's new demands is closely associated with feelings about privacy, access, freedom from interruption, and 
independence from the mundanity of living: urges that are important for the conscious modernist project that her life was becoming when she wrote her essay. She also noted that 'when human relations change there is at the same time a change in religion, conduct, politics and literature. Let us agree to place one of these changes about the year $1910 .{ }^{6}$ As such an all-embracing moment, 'December 1910' has become iconic, and has accrued a carapace of modernist studies that does not necessarily question the ideas originally expressed in connection with it. In this paper, I explore how history and the intellectual debates of the period are reflected in alternative records and popular reading, drawn from texts and material that the cook herself might have read. Access to knowledge differs considerably across the social classes. Marginalised and popular sources have an important role to play here, when it comes to assessing Woolf's judgements about 'conduct, politics and literature' and newspapers, manuals, and commercially successful novels from 1909 to 1912 hold valuable evidence for assessing social change.

One of Woolf's points was that this arbitrary moment shows increased attention to matters formerly only private and personal, allowing them to become public and communal. I discuss private family disputes, jokes between friends, the talk of gay men used in the conversations of straight women, advice to worried women by doctors and bishops, explorations by intellectual reformers of the sex language from the street, and suppressed sexual behaviour in three commercially successful novels of 1909 and 1912. By examining such outposts of the radical and the conservative simultaneously I hope to indicate how we can better understand what changes the human character was 
experiencing, and to assess whether a single moment of modernity is useful in reading history.

\section{What kind of 'human character'?}

Woolf's essay is concerned with how 'modern' writers could and should illustrate character by drawing the personal and domestic affairs of the upper and lower classes closer in their fiction. In contrast, later in her life, Woolf connected 1910 with separation rather than drawing closer, describing the rebellion of herself and her sister Vanessa in around 1900 against her father and her Duckworth half-brothers:

By nature, both Vanessa and I were explorers, revolutionists, reformers. But our surroundings were at least fifty years behind the times. Father himself was a typical Victorian: George and Gerald were unspeakably conventional. So that while we fought them as individuals we also fought against them in their public capacity. We were living say in 1910: they were living in $1860 .^{7}$

The use of 1910 here may represent Woolf's portmanteau date to represent forward-thinking 'moderns', but these remarks suggest a rupture between the generations, an awareness of anger and prohibition from the older male generation, and a shift to the idea of young women having autonomy. This is clearly a classic Victorian subject, well worked out in contemporary fiction, particularly in the Edwardian women's novel, ${ }^{8}$ and it is useful as a way to observe change in women's lives, on or around 1910. Looking for evidence of 
changes in conduct prescribed in the literature of the day (both fiction and non-fiction) can also inform our understanding of aspects of political life of the period.

Woolf's letters and diary entries up to and around 1910 are illuminating here. There is a recurring joking interest in 'passing' as a prostitute in Woolf's letters to friends, along with the subjects of sex, immodesty, nudity and pregnancy, relative to herself and others. ${ }^{9}$ On 31 December 1909, Woolf wrote to Clive Bell that Lytton Strachey, his sister Pernel, and their friend Irene Noel had been to visit her: 'We discussed love and sex and filth' ${ }^{10}$ While these letters record her bravado, they also testify to an atmosphere of open teasing about sex and its public and private manifestations in Woolf's private life, well before the end of 1910.

An undated episode recorded in Woolf's essay 'Old Bloomsbury' (read to the Memoir Club in 1922) probably took place earlier than 1907, since it was before the Bells' marriage: ${ }^{11}$

It was a spring evening. Vanessa and I were sitting in the drawing room [...] Suddenly the door opened and the long and sinister figure of Mr. Lytton Strachey stood on the threshold. He pointed his finger at a stain on Vanessa's white dress.

'Semen?' he said.

Can one really say it? I thought and we burst out laughing. With that one word all barriers of reticence and reserve went down. A flood of the sacred fluid seemed to overwhelm us. Sex permeated our conversation. The word bugger was never far from our lips. We 
discussed copulation with the same excitement and openness that we had discussed the nature of good. ${ }^{12}$

The anecdote is suggestive about the widening vocabularies of these upperclass young women, but also raises questions about how much Woolf actually knew about sex. In 'A Sketch of the Past', Woolf described her Duckworth step-brothers as sexual predators on the Stephen sisters in the family home, in alarming terms. ${ }^{13}$ Her brother-in-law Jack Hills was the first person who 'spoke to me openly and deliberately about sex', ${ }^{14}$ a conversation she recalled as benign, in Fitzroy Square where Woolf moved in 1907. Such biographical anecdotes indicate that greater openness in the relations between these men and women took place long before 'December 1910'.

The marginalized discourse of homosexual men was informing Woolf's linguistic education in private, and opening her eyes and ears. Another, parallel politicized engagement with colloquial vocabularies across the classes in radical politics also occurred earlier than 1910: free-thinking groups such as the Legitimation League were debating sex and what happened to women's bodies due to sex, to the extent that strategies were being worked out for how to make the mere words acceptable. ${ }^{15}$ According to Sheila Rowbotham:

In 1897 the British free lovers in the Legitimation League were puzzling over the existence of 'two forms of speech or language in connection with sex matters'. One was scientific and the other 'the bald, rugged phrases of the gutter and the market-place'.... This 
anxiety about language partly expressed a recognition of the practical threat they faced. They had to position themselves on the 'higher plane' if a line between sexual radicalism and obscenity was to be drawn. $^{16}$

These intellectuals' attempts to sanitize colloquialisms about sex indicate a desire for the subject to be possible in polite company. The young and unmarried were not to be the only beneficiaries. As Rowbotham observes:

By the early twentieth century, the Neo-Malthusian Alice Vickery, who was active in the propaganda drive in working-class areas of South London, presented her audiences with both individual and social reasons for birth control. Vickery ... in 1912, address[ed] the Women's Cooperative Guild in Tottenham, North London, on how 'married persons' could limit births. ${ }^{17}$

Bringing such discourse to the non-intellectual classes had clearly become part of the movement towards an enlarged vocabulary about sex. Woolf's own exposure to sexualised vocabulary was a sign of the changing conduct that Rowbotham records, once again before 1910.

These passages from Woolf's biographical writings draw together several themes. They show: classes of people learning to talk to each other for the first time; new forms of communication and vocabulary; a theoretical familiarity with sex and its impact on the female body; and familial male jealousy from the kind of man who opposes, rather than emancipates, women. 
In 'Character in Fiction' Woolf asked modern novelists to depict character in fiction in a way that would 'create characters that are real, true and convincing, ${ }^{18}$ Following this requirement, it is important to assess whether the conduct and physicality of women depicted in popular reading of this period, articles and adverts from the most popular and representative daily and Sunday newspapers of 1910, had actually reached a new level of convincing realism, in terms of contraception, abortion, and menstruation. These are taboo subjects routinely hedged around, or euphemized, in the Victorian period, not least in the case of abortion for fear of prosecution. By gauging opinions on these themes from the contemporary periodical press I follow Woolf's own opinion that 'the daily paper' is 'history in the raw'. ${ }^{19}$ A second set of primary sources, consisting of Victorian and Edwardian women's health manuals, and articles from contemporary medical literature sheds further light upon study of this journalism. The third set of popular reading sources consist of three commercially successful novels which openly addressed the increasing sexualisation of young unmarried women. This research illustrates the importance of using book history and archival material supported by close reading. The use of non-standard literary sources as well as novels structures my thinking around historical data, to offer a more nuanced understanding of the arrival of the 'modern', the Georgian versus the Victorian, as a theoretical framework installed after the event. This represents a new approach to the question of what constituted the 'modern', revealing where underexplored but significant debates took place.

\section{Stories about Women and Sex}


In 1909, the freethinker and sexual campaigner Edward Carpenter wrote: 'The subject of Sex is difficult to deal with. There is no doubt a natural reticence connected with it. There is also a great deal of prudery. ${ }^{20}$ Such concerns were radical, but also drew on current thinking, and a nascent desire for change in social conduct. As Jane Eldridge Miller notes, 'Edwardian novels about women and feminism ... entailed a radical break with social and cultural traditions. ${ }^{21}$ In this context, Grant Allen's notorious, popular novel The Woman Who Did (1895) offers one depiction of how a woman might offer sex to a man as an equal outside marriage:

I am yours this moment. You may do what you would with me.... How could you fancy I spoke hastily or without due consideration on such a subject? Would you have me like the blind girls who go unknowing to the altar, as sheep to the shambles? $?^{22}$

This is an early example of how British literature had been exploring this subject since the 1880s. The reviewer of H. G. Wells' novel Ann Veronica (1909) in T. P. 's Weekly summarised its relationship with such a 'sex novel': 'it shares the responsibility of a futile meddling with the marriage tie, and a tendency to glorify the woman who has had sexual adventures. ${ }^{, 23}$

The commercial success of these novels was an indicator of intense interest in the subject: Ann Veronica was the classic account for the Edwardians. David Smith explains that along with Wells' In the Days of the Comet (1906), 'people did not read [these novels] in polite company. They were to be smuggled away to read alone. Mothers and aunts often forbade 
these books [because] reading them brings titillation. It makes no difference that this view of them is untrue. What matters is the perception. ${ }^{24}$ Ann Veronica had been rejected by Frederick Macmillan, Wells' usual publisher, who called it "“exceedingly distasteful", "not amusing", and "certainly unedifying", ${ }^{25}$ John Buchan, of Wells' Presbyterian reprint publisher Thomas Nelson \& Sons, called Ann Veronica 'indefensible'. ${ }^{26}$ After Wells sold Ann Veronica to T. Fisher Unwin, however, he reported to Macmillan that it 'is selling very fast here and in New York' ${ }^{27}$ It has never been out of print.

The attitude of Ann Veronica's father, Mr Stanley, towards women and sex is as significant to our themes as his daughter's sexual adventures. $\mathrm{He}$ objected to his wife's continual pregnancies. He 'had always felt (he had never allowed himself to think of it) that the promptitude of their family was a little indelicate of her' (p.15): it clearly has nothing to do with him. His daughter desires more to her life than waiting blindly for marriage, and goes to college to study biology, where she falls in love with, and elopes with, her professor. Mr Stanley's iteration of the jealous father and the angry Victorian male confronting the liberated Edwardian female blames fiction for Ann Veronica's behaviour: 'It's these damned novels. All this torrent of misleading, spurious stuff that pours from the press. These sham ideals and advanced notions, Women who Dids and all that sort of thing...' (p.27). Mr Stanley's unexpected knowledge of Allen's novel is likely to have come from a general Georgian understanding perpetrated by the media that the Woman Who Did was a synonym for all uncontrolled and scandalous young women: again, nothing to with him. 
However, Ann Veronica's autonomy in love and sex is held back by her author. For all his advanced thinking, Wells cannot move away in this novel from the idea that sex is the only thing a woman is for: his attitude is no better than that of Ann Veronica's attempted seducer Ramage. Ann Veronica only reaches fulfilment through the love and financial support of a good man. Her husband Capes can succeed in his new writing career, but we hear nothing about what she has done except grow taller and get pregnant after four years of co-habitation. Ann Veronica's aunt offers no congratulation on hearing that they are expecting a baby. 'I think - I judge from her manner - that she thought it was just a little indelicate of us - considering everything' (p.285). We can infer that the 'everything' is co-habitation with contraception, as well as defying Mr Stanley’s wishes. Wells could not be more explicit: he could not jeopardise the commercial success of a novel he depended on for income, and literary reputation.

The most interesting ideas presented in this novel about women and sex are voiced by Ann Veronica's friend Hetty Widgett, a mouthpiece for truth:

We're inflammable litter that mustn't be left about. We are the species and maternity's our game; that's all right, but nobody wants that admitted for fear we should all catch fire, and set about fulfilling the purpose of our beings without waiting for further explanations. As if we didn't know! The practical trouble is our ages. They used to marry us off at seventeen, rush us into things before we had time to protest [... They don't marry most us off now until high up in the twenties. 
And the age gets higher. We have to hang about in the interval. There's a great gulf opened and nobody's got any plans what to do with us. So the world is choked with waste and waiting daughters. (p.38)

In Edwardian fiction, as Miller argues, one of the functions of the rebellious heroine was to "blatantly contradict conventional ideas about femininity and female behaviour'. ${ }^{28}$ Wells' achievement was in showing what might happen if a match were set to the inflammable daughters who had been waiting for some time.

Ann Veronica's desires were not radical in 1909, but familiar. Looking beyond fiction, Virginia Nicholson records how, in the summer of 1912, Rosalind Thornycroft and Godwin Baynes were allowed by her Fabian parents to visit Paris together, unmarried and alone. They lived together in London for a year after that, with her sister as a chaperone, and did not marry until 1913. This 'was a way of life that was lived by many of our contemporaries of advanced people among Fabians and students' ${ }^{29}$ This account from the first generation of twentieth-century sexual radicals testifies to changing social conduct that drew on common practice from a different class. . Evidence given to the Royal Commission on Divorce in March 1910 included the opinion of a Hull stipendiary that 'separated people did form irregular unions - it was a serious ill', and 'a co-respondent in the upper classes suffered a social penalty [on separation], but so slight was the social penalty in the case of the working classes that he had even known cases of wives and chjldren sold for pints of beer'. ${ }^{30}$ Such a pragmatic attitude to cohabitation outside marriage became intellectualised in the hands of the liberal classes. The Daily Mirror of 9 
February 1907 reported a public lecture in Bloomsbury Hall by a Dr D J Stenson Hooker, arguing for the abolition of divorce and marriage, and advocating cohabitation. ${ }^{31}$

The second novel under discussion, Una L. Silberrad's Ordinary People, also from 1909, is much less well known. Its ‘ordinary' heroine, Catherine, has a secret that prevents her happiness until the end of a complex plot of modern stratagems for survival on the edges of polite society, for she was seduced as a young girl by her father's friend, abandoned, and had an illegitimate baby who died. This novel was published by Constable \& Co, and reprinted in a cheap edition in 1912 by Thomas Nelson, who clearly did not find the illegitimate baby or the seduction of a 17 year-old girl 'indefensible'. Neither the Nelson's reader's report, nor the reviews of Ordinary People, mentions these startling events in Catherine Santerre's life. How indicative is it of a modern attitude to women's sexual conduct that such a morally dubious subject could be described as 'ordinary' in 1909? One answer lies in Silberrad's constant moral buttressing of Catherine's life and choices. She is a classic victim of male predators, in a line of fiction that began with Samuel Richardson's Clarissa (1748). Her father is profligate with no sense of responsibility, and she is further dragged down by a governess companion of shabby character. ${ }^{32}$

Santerre's venality contrasts with the respectable middle-class suburban life and personal probity of Catherine's future husband John Cobham; this in turn absolves Catherine of sharing her father's values, which she knows are 'unclean'. ${ }^{33}$ Her innate sense of honour is indicated by her statements that if she cared anything for Cobham, she would not agree to 
marry him, or bring her shame into his life (p.79, 94-96). These marks of her respectability reduce the moral obloquy of her sexual past. Her dead illegitimate baby is only mentioned obliquely, in tropes of arrested maternity, and a sentimental fragility over small children. It symbolises Catherine's vulnerability and perfect maternal instincts. After her marriage temporarily breaks down, Catherine refuses to use her marriage settlement, works for the impoverished Cobham in disguise as his typist, nurses him through pneumonia, and diverts further fraud from her father's sharp practices. When this tale of two honourable people adrift in a sea of dishonourable behaviour is resolved, Catherine continues to redeem any taint of her past by symbolic abasement, asking to learn to dust and clean their house herself, and works in a maternity club, with a particular interest in helping the 'mothers who had no right to have babies $[\ldots]$ when they were young and friendless.' 34

These acts of atonement to society are rewarded by the suggestion that her perfect husband will understand her innocence without needing to know details. This modern common sense disassociates Victorian sensation morals from the practical effort needed in making a marriage work. The morally problematic subjects of the unmarried mother, and the child who should not have been conceived, are treated with Silberrad's Quaker principles of forgiveness and honesty to show how neglect of the vulnerable is criminal. This, Silberrad shows, is far more damaging to the relations between men and women in 1909 than interfering moral shibboleths.

The final popular novel to be examined is Joseph Conrad's Chance (1913), which was being revised and rewritten from 1911 and serialised in 1912. Susan Jones describes it as his 'first economically successful venture in 
reaching a wider audience and addressing the themes of gender and romance'. ${ }^{35}$ More importantly, Chance is about its heroine rather than about the men who manipulate her. ${ }^{36}$ As Jones observes, the plot of Chance is 'a topical and challenging response to the contemporary debate about "being" a woman'.37

Middle-class Flora de Barral is abandoned when her father goes to jail, and finds herself dangerously at risk from sexual predators. 'The girl for all her experience was still too innocent, and indeed not yet sufficiently aware of herself as a woman, to mistrust these masked approaches. ${ }^{, 38}$ The last part of the novel is an agonising account of de Barral's vicious persecution of his daughter and her husband, Captain Anthony, which descends past jealousy to a mania that Flora has sold her body unworthily and is now a fallen woman. 'Of course you are pretty. And that is why you are lost - like many other poor girls. Unfortunate is the right word for you' (p.285).

His possessiveness is a variation on the Victorian father objecting to the autonomy of the Georgian young woman. Conrad reinforces the troubling idea of a sexualised daughter with explicit references to Captain Anthony as Othello, and Flora as Desdemona. Marlow the narrator amplifies this with comments on the natural feelings of a father at his daughter's sexual awakening: 'At bottom, quite deep down, down in the dark (in some cases only by digging), there is to be found a certain repugnance' (p.275). The novel is full of suppressed or marginal sexualities. Flora herself is a young woman who has learned desire but cannot act on it. The irony in de Barral's persecution of his daughter is that her marriage has not been consummated, due to Captain Anthony's gentlemanly scruples. Jones positions this as a 
deliberate displacement of the Victorian romance plot by Conrad, 'that threatens to displace social conventions, assumptions about gender roles, and the structure of romance itself' ${ }^{39}$ Marlow's observation, 'If two beings thrown together, mutually attracted, resist the necessity ... and voluntarily stop short of the - the embrace, in the noblest meaning of the word, then they are committing a sin against life,' (p.316) can be read as a statement against nonconsummation. Like Wells, Conrad is arguing that the contemporary woman's identity is predicated only on her limited sexual role. ${ }^{40}$ Flora is, serially, the vulnerable heiress, the predated 'lady-companion', the friendless unmarried woman, and the wife without a choice: all defined by patriarchal convention. Flora's enforced chastity, which chafes as she grows more attracted to her self-denying husband, is a realistic reflection of contemporary beliefs in chastity as a feminist act, advanced by the Legitimation League, among other radical groups. ${ }^{41}$ Flora is not feminist, and wants to be 'properly' married, yet this cannot be expressed by Conrad except in highly oblique terms. As Jones argues, by 'presenting the isolation of a woman caught between conflicting ideologies, Conrad ironizes both patriarchal and feminist positions. ${ }^{, 42}$

Wells and Conrad felt able to write relatively explicitly about the natural physical consequences for women of entering marriage in these novels aimed at a popular market, without running too much risk of being prosecuted. Silberrad's Ordinary People goes further, but protects the heroine from moral blame by overt acts of atonement. The emphasis on the sexual jealousy, or indifference of the father, in all three novels, makes an uncomfortable juxtaposition. In terms of language, Marlow's contorted, Jamesian, narration of Chance obscures as much as it reveals. Wells was unable to go as far as he 
might have wanted to. Silberrad hides her sexualised information in Victorian sentimentality, but presents moral failure openly. There are no brave new discourses on the sexuality of women in these novels, yet the subject has become respectable, and the readers are expected by their authors, if not by the publishers, to decode the meanings without shock.

\section{Historical Accounts}

Women's bodies and their sexual roles are also represented in nonfictional daily reading within newspapers, providing further evidence for evaluating Woolf's statements about social change in 1910. There are strong synchronies between the literary and the archival material examined here, not least because the novels reveal the ephemeral traces of human relationships that we can deduce from the historical record. In complementing each other, they reconstruct history more persuasively.

Using surveys by James Startt and Alan Lee to determine which newspapers were most popular in 1910, I examined the Daily Mail, the Daily Express, the Daily Chronicle, the Daily News, the Evening News, the News of the World, and the Sunday paper Reynold's Newspaper for various months in $1910 .{ }^{43}$ Advertisements in some of these publications routinely filled the double-spread centre columns and the outer and corner areas of pages following the main part of the news, and commonly addressed the challenges of the body. Most of the adverts for quack medicines had appeared for decades, encouraging trust by their familiarity. Surveying these advertisements, it is quickly clear that not offending the reader was more important for the newspaper and its sales, than in communicating modern 
ideas about the physical needs of the body. Avoiding offence also had legal implications, since some of these adverts had highly dubious interpretations. Reynolds's Newspaper carried a 'Children's Corner' feature on its main advertisements page, indicating a mixed family readership; it offers a particularly rich field for these advertisements, offering a wide range of cures for physical ailments. Many conditions were familiar from those advertised in Victorian periodicals: they include hair loss, weight loss, consumption, green sickness, rupture, low energy and bowel regularity. Products for restoring physical competence and fitness were explicitly directed at a male market, but achieving greater regularity as relief from constipation was a concern for both sexes. The desirability of regularity for the body was overwhelming, iterated by a torrent of repeated adverts in multiple media. It was presented as a routine ailment, easily cured, by multiple remedies: one only had to order one's usual product and be comfortable again. Such routine drug-taking to cure the result of an unhealthy diet was also condemned by health advice, but eating the required fresh fruit and vegetables would have been too expensive, then as now, for the underclasses which Reynold's Newspaper in particular addressed.

In an extension of the normalization of regularity, the language of some of these advertisements is striking for the way in which it uses a code designed to be understood by those who knew what to look for, but without attracting legal attention. 'The law against the sale of abortifacients was almost unenforceable ${ }^{44}$ For women, reimposing regularity, and the removal of obstructions that were impeding regularity, was presented as a way to restore regular menstruation, as these examples show: 
Free to ladies Horton's Original Benedict Pills. In a few days correct all irregularities and also cure Anaemia and cause no injury. To the married or single are invaluable.

Ladies. Do Not Fail. Mme Constantine, the registered lady specialist, will be only too pleased to send full particulars about her great discovery, how all ladies can cure themselves at home of all irregularities without the use of pills, mixtures or any medicine whatsoever. It will not interfere with the ordinary duties of life. It is also the most positive, safe, sure and speedy cure that has ever been disclosed to the public. It is practically impossible for any case to fail.

Free to Ladies. Free to ladies. A sample of the most reliable remedy ever discovered for irregularities can be had post free. Thousands of letters of thanks testifying to the speedy efficacy after all other things have been tried in vain. [...] Guaranteed effective in a few hours. Impossible to Fail. Delay is dangerous.[...] Send at once to Nurse R. N. Mann, 11 Old Compton Street, London W. ${ }^{45}$

This imposition of regularity for women was read as a euphemism for the procuring of early abortion by the inducement of spontaneous miscarriage. ${ }^{46}$ According to Nigel Brown: 
One theme of these publications was that some of the medicines were advertised in such a way as to suggest to prospective purchasers that they were intended as abortifacients. This view was supported by the wording of some of the advertisements quoted, such as that for Mr. P. Blanchard's medicine, which 'should not be taken by those expecting to become Mothers, as it is sure to produce a miscarriage'. [...] The sale by some proprietors of a series of medicines of ascending strengths (at increasing prices), accompanied by letters of encouragement and appropriate instructions, also suggests that the object of the medicines was to terminate pregnancy rather than cure amenorrhoea from other causes. ${ }^{47}$

The coded vocabulary was vital to avoid prosecution. 'Under successive acts since 1803, the last being the Offences Against the Person Act 1861, abortion was outlawed with the penalty rising to life imprisonment, and it was a lesser offence knowingly to supply others with instruments or medicines for the purposes of inducing abortion'. ${ }^{48}$ The terminology used in these adverts used a vocabulary designed to be known to women of the lower middle classes and working classes reading Reynold's Newspaper, and other papers carrying these ads. This may prompt us to ask whether the Stephen sisters would also have understood the code. Would they have read their cook's copy of the paper? It may be unclear how widely known it was that inducing one's own abortion was illegal. Rowbotham notes that 'in 1929 in Mother England Marie Stopes reported: "In three months I have had as many as twenty thousand requests for 
criminal abortion from women who did not apparently even know that it was a crime".,49

The vocabulary used in these adverts was predicated on the woman as a mother and a housekeeper by their location amongst the features for the Children's Corner and below illustrations of children with their mothers. Some adverts reassured the anxious that the treatment 'does not interfere with household duties'. ${ }^{50}$ Medical authority was frequently invoked, with the use of 'Nurse' or Doctor' in the address, or in the advert, and reassuringly familiar ingredients given, such as pennyroyal and bitter apple. The overall impression of the headlines alone, on such pages, was of reassurance, confidence, and of all life's problems meeting in the pages of the newspaper. From 6 February 1910, by reading across the page from left to right, row by row, we can read the following headlines alone, of features and adverts:

Reynols's Home Page - New Models for Petticoats - How to Use Them - Hints to Mothers - 40 Years with a Bad Leg - Linola - Great Winter Sale - Brown's Bronchial Troubles - Tired Eeyes - Singleton's Eye Ointment - Mrs Winslow's Soothing Syrup - The Ruptured - Salmon Ody Trusses Marriage and Its Mysteries - Ellis's Pills for Females - After Season Bargains - The Importance of a Good Fitting Garment - Answers to Correspondents Cancer Cured At Home - Important to Ladies - Useful Flannel Petticoat Ladies Send At Once for Particulars - Strong Nerves - Household Hints Ladies! Ladies! - Every Woman - Dr Blanchard's Wonderful Pills - Free Teeth - The Children's Corner - To Ladies - Free Offer to Weak Men Eade's Gout Pills - Presentation Copy of the Wife's Handbook - Free to 
Women - Free to ladies Horton's Original Benedict Pills - A Reliable

Remedy - To Ladies Read This - Indigestion - Given Away.

There is considerable irony in the positioning of features urging the maintenance of a good figure across the page from adverts purporting to offer remedies for unwanted pregnancy, as is the frequent juxtapositioning of illustrations of a idealised blonde and ringleted child and adverts offering to 'remove irregularities'. The repeat appearance of these adverts in newspaper pages, over many years, without change in the copy or layout, makes them as familiar as wallpaper, and possibly also as unread and unnoticed, except when the need arose. It is unknown how many women applied for the remedies, but the simple economics of the adverts continuing to appear argues that there was some profit in this business, in this sector of the media at least.

Suggestions of abortion can be found elsewhere in earlier popular reading matter. The Girls' Own Paper of November 1900 carried an Answer to Correspondents discussing a 'criminal operation': 'We know that the operation has been performed frequently, and, by some of the most experienced specialists in England, but it is a most serious crime to perform it.' The editor's decision to include this, and other instances of unusually open advice to its readers, was sternly opposed by the religious principles of the publisher, D. C. Thompson. ${ }^{51}$

On the question of reproductive health, offers of price lists for contraceptives, or 'Malthusian advice', and sanitary protection supplies by mail order were occasionally discreetly present in the sample of newspaper advertisements examined. The Wife's Handbook, cited above, was a familiar presence, according to Nicholson: 'The Wife's Handbook (1887) by Dr H. A. 
Allbutt was in print for several decades and, despite attempts to prosecute its author for obscenity, reached its forty-first edition by 1910. It was full of useful information about preventative measures in the form of sheaths, Dutch caps, sponges, tampons and the like. ${ }^{, 52}$ Even newspapers could advise on contraception, in selected features for advanced readers. As Rowbotham records, 'Julia Dawson, a columnist on the British socialist paper, the Clarion, recommended a birth control tract in 1896 which demonstrated how to make pessaries from cocoa butter and quinine. ${ }^{53}$ The adverts for contraception in Reynolds' Newspaper were coded in the same fashion as the abortifacient and 'regularity' ads, indicating a shared concern with the coding of taboo information, here also aimed at women.

Given away. Presentation copy of the Wife's Handbook. Containing volumes of information for the Married. Contains knowledge worth XXXX pounds. Send for illustrated catalogue of rubber surgical appliances post free.

Given away! Words of wisdom for our wives. Being a new treatise of advice and information for the married. It is fully illustrated and contains the population question and other information worth HUNDREDS OF POUNDS. ${ }^{54}$

But there were far more adverts discussing bowel regularity than menstrual regularity, suggesting that the needs of women's bodies were very much present, but also under social taboo. Even California Syrup of Figs, 'Nature's 
pleasant laxative', was marketed for children, whereas such openness about bodily function was denied to the uterus for fear of offending. ${ }^{55}$

Late Victorian and Edwardian health manuals provide more targeted information. George H. Napheys' Physical life of Woman (1895) reprinted a section from an American edition of 1869 that discussed menstruation in detail, but without practical advice on its daily management. According to Vickers and Eden, Napheys' 'assertion that "menstruation starts at fourteen years and six months" represents the need for physical womanhood to be regulated by medicine, ${ }^{56}$ and the need for a young woman to achieve mastery over her body as well as her social conduct. Napheys remarks that 'the solicitude of parents has been excited in the long delay in this constitutional change', and asserts that the responsibility for vigilance rests with the mother of a daughter with delayed menstruation. ${ }^{57}$ This is repeated in the advertisements of 1910 that play on similar parental concerns. As Vickers and Eden note, 'Irregularities' are expected to 'right themselves' ${ }^{58}$ Women are decreed to be ready for marriage, or 'nubility', between twenty and twentyfive years. Again, the regulation of the body, particularly that of the growing woman, was decreed by medicine. ${ }^{59}$

Haydn Brown's Advice to Single Women Regarding their Health With Hints Concerning Marriage (1899, reprinted in 1907 and 1908) warns sternly against using drugs to bring on the 'monthly courses', and calls the practice of inducing 'regularity' positively dangerous. ${ }^{60} \mathrm{He}$ addressed other aspects of regularity, in twenty-one pages devoted to offering advice about constipation, and twenty pages on tight lacing (another aspect of regularity), compared to only eleven pages on menstruation. He also gave alarming hints about sexually 
transmitted diseases, which he stated he could not detail 'without running the risks of communicating indecent information'. ${ }^{61}$ Once again, we see that a code needs to be used for certain information to be transmitted, and once again it concerns women's bodies in a manual available long before 1910 .

The obstetrician Florence Stacpoole's Women's Health and How To Take Care of It (1906) offers a more advanced approach, with warnings about what ought and ought not to be inserted into women's bodies. Her warnings about glass syringes are particularly terrifying, but her focus is largely on constipation and on coping with menstruation. She was firm about censoring information, saying that girls needed to be told about menstruation, but not anything about their relationship to sexual matters, 'concerning which the less very young girls know or think the better'. ${ }^{62}$ She too warned against drugs for menstrual regularity, in terms that could, possibly, be decoded as a warning against inducing abortion. ${ }^{63}$ She noted that periods were naturally irregular: a point which is not found in earlier manuals, indicating a greater awareness of natural irregularity by this date, or perhaps only her easier access to the facts as a woman herself.

Adverts for products to combat anaemia, which we can read as irregular and insufficient menstruation, or the results of a menopause exhibiting heavy flooding, were frequent in the newspapers, and lyrical in their enticements. In the Daily Mail, for example, we find:

Probably nine women out of ten find, at one time or another, that their outlook on life has been affected, more or less seriously, by the common enemy of the sex - poverty of the blood. Frequently, just at 
the time when the young girl needs an abundance of good, rich, red blood to carry her through to womanhood, Anaemia stamps its curse upon her. Then again, those of more mature years, and matrons at the time when strength declines, find themselves face to face with obstinate sufferings that all arise from weak and impure blood. ${ }^{64}$

However, many anaemia remedies were also marketed as a cure for St Vitus Dance, bronchitis and neuralgia, and other conditions. This includes 'Phosferine: the greatest of all tonics, a proven remedy for exhaustion, maternity weakness, anaemia', advertised in the Daily Express. ${ }^{65}$

Going back to the newspapers, we are reminded that the news itself can be instructive on secret and coded matters of sex. The law reports from the criminal courts, described at length every week in the News of the World ans in Reynolds's Newspaper, gave detailed instruction on the practical aspects of committing adultery and being caught, how to be a co-respondent, and foolish and imprudent sexual behaviour. In 1910, each week's issue carried multiple stories and headlines featuring women doing wrong: being drunk, committing murder, conducting divorce, arranging abductions, and in court. Headlines alone gave clues to sensational stories. From a page and issue selected at random we find the following: Barrister and his Wife - Girl's Sad Story Smacked her Face - Countess's Lovers - Amazing Story of the Wiles of a Modern Delilah - Drama of Jealousy - Lover's Confession - Delighted in Pain - Her Abject Slave. ${ }^{66}$ Adverts for menstrual regularity were juxtaposed with reports of breach of promise cases. Sexualised activity was by 1910 already explicit in all but the most prosecutable details, if you knew where to look. 
One wonders how the Victorian father would expect his Georgian daughter to stay ignorant of modern behaviour, and content with Victorian conditions at home, if she had access to these periodicals, even second-hand.

The Bishop of Stepney offered his opinion in a book puffed at length in the Daily Mail of 23 July 1910: Home Life in England concerns the antagonism of parents and children, with filial ingratitude and irresponsiveness contrasted with the parents' conviction of injustice and lack of understanding, particularly at this date. An anonymous writer observes, 'It seems to be the Bishop's opinion that home life today is passing through a time of test and strain. ${ }^{97}$ The subheadings 'The treatment of daughters' and 'Mistakes with daughters' show that women were singled out by this feature about a book that appears to treat sons and daughters equally. It is interesting that this example of the sensational but safe conservatism within the daily press targeted the Georgian girl in opposition to her Victorian parents at exactly the time that Wells's and Silberrad's novels about the problem were freshly in print. Daughters also feature in an adjoining feature: 'Dress at Seventeen. Clothes for the Young Girl' offered further advice to parents on how to keep their daughter happy but under control, directly underneath the Bishop's photograph. The generation gap was being addressed overwhelmingly, on a topic presented as familiar, and relevant to all its readers. Decidedly, the novels examined earlier resonate with this archival evidence.

\section{Conclusion}

We can see that ideas connecting the jealous Victorian father and the emancipated Edwardian girl in and about 1910 are closely associated with 
ideas about the emancipation of the vocabulary and codes concerning women's bodies, in terms of their physical collocation. Going back to 'Character in Fiction', Woolf cites the example of Arnold Bennett's Hilda Lessways (1911) as an example of whether Bennett could make Hilda 'feel real, true and convincing, as a novelist should ${ }^{68}$ Although Woolf chose this novel because it was 'the first book that chance puts in my way' (notice the title of Conrad's novel lurking in her lexis), it is, also, a notorious novel written 'on or about 1910', in which the pregnancy of an deserted married woman, whose marriage is not known, forms the centre of the plot. The conventions are upheld, but only just, while the public, sensational aspects of her situation attract more attention to her detriment. Scandal and morality struggle for dominance, as they did in Ordinary People, as in Chance, and in Ann Veronica. All four writers were writing about the line over which modern women should not step in terms of sexual behaviour. These fictional characters make forays onto the risky side, mimicking publicly reported extracts from criminal court proceedings, with consequences that could be inferred from the adverts in the cheaper Sunday press. Can we deduce whether these characters were 'real, true and convincing'? They fit into the world we read about in the health manuals, and in the discourse of the newspaper adverts, where secret information about the mysterious imperative of women's regularity was common knowledge and also coded knowledge. Educated men and women would have understood the adverts for what they were, simply through an increasing dissemination of sexualised and socialised language from other social spheres. 
This plethora of common knowledge and decodable knowledge, across classes, sexes and ages, available freely and widely in 1910, and for many decades before that, suggests an important conclusion to my investigation that Woolf was many years off the mark in her pinpointing of December 1910 as the moment when human character changed, in terms of sexualised knowledge. The common parlance of modernity, with regard to women's bodies, had already arrived by 1910 .

\section{Notes}

${ }^{1}$ Virginia Woolf, 'Character in Fiction' in The Essays of Virginia Woolf: Volume Three: 1919-1924, ed. Andrew McNeillie (London, 1988), p. 421. I am exceedingly grateful to Stephen Donovan, Uppsala University, for his critical support while writing this article, and for the loan of books and ideas.

2 'Character in Fiction', p.422.

${ }^{3}$ Alison Light, Mrs Woolf and the Servants (London, 2008).

${ }^{4}$ 'Character in Fiction', p.422.

${ }^{5}$ Peter Stansky, On or About December 1910. Early Bloomsbury and its Intimate World (Cambridge, MA, 1996), p.4.

${ }^{6}$ 'Character in Fiction', p.422.

${ }^{7}$ Virginia Woolf, 'A Sketch of the Past', in Moments of Being. Unpublished Autobiographical Writings (London, 1976), pp.64-137, 127.

${ }^{8}$ Jane Eldridge Miller, Rebel Women. Feminism, Modernism and the Edwardian Novel (London, 1994).

${ }^{9}$ The Letters of Virginia Woolf. Volume One 1888-1912, eds. Nigel Nicolson and Joanne Trautmann (New York, 1975), 11 September 1898, p.19; 13 
March 1899, p.20; 17 June 1900, p.33; 10 April 1903, p.73; 17 September 1907, p. 207; 10 August 1908, p.348; 13 May 1909, p.394; 11 October 1909, p.418; 13 June 1910, p.427; 24 June 1910, p.429; August 1910, p.432; 8 September 1910, p. 435; 14 November 1910, p. 438; 27 November 1910, p.440.

${ }^{10}$ Virginia Woolf to Clive Bell, 31 December 1909, Letters, p.418.

${ }^{11}$ Woolf mentions meeting Strachey in a letter of 1901. Quentin Bell, Virginia Woolf. A Biography (New York, 1972), p.69.

${ }^{12}$ Virginia Woolf, 'Old Bloomsbury', in Moments of Being, pp.159-79, 173.

${ }^{13}$ Woolf, 'Sketch', p.69; Virginia Woolf '22 Hyde Park Gate', in Moments of Being. pp.142-55, 150, 155.

${ }^{14}$ Virginia Woolf, ‘Sketch', p.103.

${ }^{15}$ The Legitimation League was founded in 1893 to campaign for free love and the abolition of conventional marriage. Its journal The Adult, sub-titled 'The Journal of Sex', was shut down after pressure by the police in 1899 . Edward Royle (ed.), Religion, Radicalism and Freethought in Victorian \& Edwardian Britain. Collection of Periodicals, 1834-1916. Pub. No. R17157, Microform Academic Publishers (Wakefield: EP Microform Ltd, nd). <http://www.microform.co.uk/guides/R17157.pdf >.

${ }^{16}$ Shelia Rowbotham, Dreamers of a New Day: Women Who Invented the Twentieth Century (London, 2010), p.68.

${ }^{17}$ Rowbotham, Dreamers, p.90.

18 'Character in Fiction', p.421.

${ }^{19}$ Virginia Woolf, Three Guineas (London, 1938), p.14. 
${ }^{20}$ Edward Carpenter, Love's Coming-of-Age: A Series of Papers on the Relations of the Sexes (London, 1909), p.7.

${ }^{21}$ Miller, Rebel Women, p.7.

${ }^{22}$ Grant Allen, The Woman Who Did (1895), quoted in Juliet Gardner, The New Woman: Women's Voices 1880-1918 (London, 1993), pp.165-6.

${ }^{23}$ John O'London, review of Ann Veronica, T. P. 's Weekly, 22 October 1909, pp. xiv, 537-8; quoted in Patrick Parrinder (ed.), H. G. Wells. The Critical Heritage (London, 1992), p.164.

${ }^{24}$ David C. Smith, H. G. Wells. Desperately Mortal, A Biography (London, 1986), p.180.

${ }^{25}$ Smith, H. G. Wells, p.231.

${ }^{26}$ John Buchan to George Brown, 25 May 1910, Thomas Nelson

Collection/Edinburgh University Special Collections, B/2/84a.

${ }^{27}$ Smith, H. G. Wells, p.112.

${ }^{28}$ Miller, Rebel Women, p.4.

${ }^{29}$ Nicholson, Bohemians, pp.37-8.

${ }^{3030}$ Daily Mirror, 15 March 1910, 5.

${ }^{31}$ Daily Mirror, 9 February 1907, 15.

${ }^{32}$ Una L Silberrad, Ordinary People (London, 1912), p.84.

${ }^{33}$ Ibid., p. 247.

${ }^{34}$ Ibid., p.375.

${ }^{35}$ Susan Jones, Conrad and Women (Oxford, 1999), p.3.

${ }^{36}$ Ibid., p.100.

${ }^{37}$ Ibid., p.101. 
${ }^{38}$ Joseph Conrad, Chance (1913), ed. Martin Ray (Oxford, 2002), p.137. All subsequent quotations are taken from this edition. Page numbers will follow in brackets.

${ }^{39}$ Jones, Conrad, p.106.

${ }^{40}$ Ibid.

${ }^{41}$ Ibid., p.110.

${ }^{42}$ Ibid., Conrad, p.110.

${ }^{43}$ James D Startt, 'Good journalism in the era of the New Journalism. The British Press, 1902-1914', in Joel H Wiener (ed.) Papers for the Millions. The New Journalism in Britain, 1850s to 1914 (New York, 1986), pp.275-98; Alan J Lee, The Origins of the Popular Press in England (London, 1976).

${ }^{44}$ Lionel Rose, The Massacre of the Innocents. Infanticide in Britain, 18001939 (London, 1986), 86.

${ }^{45}$ Reynolds' Newspaper, 4 December 1910, p.12.

${ }^{46}$ Anon, 'The composition of certain secret remedies', British Medical

Journal, 1 July 1911, pp.32-7.

${ }^{47}$ Nigel Brown, 'Female pills and the reputation of iron as an abortifacient', Medical History 21 (1977), 291-304, 300.

${ }^{48}$ Lionel Rose, The Massacre of the Innocents. Infanticide in Britain, 18001939 (London, 1986), 86.

${ }^{49}$ Rowbotham, Dreamers, p.100.

${ }^{50}$ Advert, 'Ladies Send at Once for Particulars', Reynolds's Newspaper, 9 Janaury 1910, p.11.

${ }^{51}$ Anon, Answers to Correspondents: Reply to 'Ixia Blossom', The Girl's

Own Paper, 22: 1090, 17 November 1900, p.112; Joseph McAleer, Popular

Reading and Publishing in Britain, 1914-1950 (Oxford, 1992), p.220. Cynthia Ellen Patton, “"Not a limitless possession”. Health advice and readers' agency in The Girl's Own Paper, 1880-1890', Victorian Periodicals Review, 45:2 
(Summer 2012), 111-133, 111-12. Thanks to Cynthia Patton, Emporia State University, and Terri Doughty, Vancouver Island University, for their assistance with this point.

${ }^{52}$ Nicholson, Bohamians, p.57

${ }^{53}$ Rowbotham, Dreamers, p.90.

${ }^{54}$ Reynolds' Newspaper, 4 December 1910, p.12.

${ }^{55}$ Daily Mail, 15 December 1910, p.9.

${ }^{56}$ Roy Vickers and Jacky Eden (eds.) ‘George H. Napheys. Physical Life of Woman', in Conduct Literature for Women. 1830-1900. Vol 5. Health (London, 2006), pp.163-222, 164.

${ }^{57}$ Ibid., p.169.

${ }^{58}$ Ibid., p.176.

${ }^{59}$ Ibid., 186.

${ }^{60}$ Haydn Brown, Advice to Single Women Regarding their Health with Hints concerning Marriage (London, 1899), p.41.

${ }^{61}$ Ibid., p.138.

${ }^{62}$ Florence Stacpoole, Women's Health and How to Take Care of It (Bristol, 1906), p.4.

${ }^{63}$ Ibid., p.5.

${ }^{64}$ Daily Mail, 5 December 1910, 3.

${ }^{65}$ Daily Express, 6 December 1910. 3.

${ }^{66}$ Reynolds's Newspaper, 13 March 1910. P.5.

${ }^{67}$ Anon, 'A Crisis in Home Life', Daily Mail, 23 July 1910, p.9.

68 'Character in Fiction', p.429. 


\section{Address for Correspondence}

Dr Kate Macdonald, Department of Literature: English Studies, Ghent University, Blandijnberg 2, 9000 Ghent, Belgium.

Email: kate.macdonald@ugent.be 